\title{
Apotheosis of Mortal Man: Stellar and Terrestrial Imagery in Dylan Thomas's Poetry
}

\section{Ölümlü İnsanın Tanrısallaştırılması: Dylan Thomas Şiirinde Yıldız ve Yeryüzü İmgeleri}

\author{
Fahri ÖZ ${ }^{1}$ \\ Ankara University
}

\begin{abstract}
Dylan Thomas's poetry is replete with the images of life and death and their cyclicality and rebirth. Such images include stars that stand for human beings' potential to reach godly heights on the one hand, and the grass that symbolizes their mortality on the other. Such images appear most prominently in his elegies "After the Funeral", "And death shall have no dominion", "Do not go gentle into that good night" and "Fern Hill", which harbours pastoral elements. The images in these poems can be treated as a strong sign of his interest in paganism. The analysis of such images can provide us with clues about the elucidation of Thomas's marginal yet indispensible place within English poetry since these images attest to the fact that he was not only influenced by English Romantic poets like John Keats but also Nineteenth-century American poets like Emily Dickinson and Walt Whitman.

Key Words: Apotheosis, Rebirth, Paganism, Stars, Earth, Elegy, Pastoral, Tradition
\end{abstract}

Öz

Dylan Thomas'ın şiirleri yaşam-ölüm çevrimselliğini ve yeniden doğuşu imleyen imgeler açısından zengindir. Bu imgeler arasında insanın ölümlü varoluşunu gösteren çimenler olduğu kadar onun tanrısal bir konuma erişebilme gizilgücünü simgeleyen yıldızlar da yer alır. Söz konusu imgeler ağıt türüne dâhil edilebilecek"After the Funeral", "And death shall have no dominion", "Do not go gentle into that good night" ve pastoral ögeler içeren"Fern Hill" adı şiirlerinde öne çıkmaktadır. Bu șiirlerdeki imgeler şairin paganizme olan derin ilgisinin bir göstergesi olarak değerlendirilebilir. Zira Thomas'ın şiirlerinde bu imgelerin irdelenmesi onun İngiliz şiirindeki sıra dışı konumunun ve şiir geleneği içinde yerinin daha iyi anlaşılması için önemli ipuçları vermektedir. Zira, Thomas'ın şiirlerinde kullandığı imgeler ve izlekler onun sadece John Keats gibi romantik İngiliz şairlerinden değil aynı zamanda Emily Dickinson ve Walt Whitman gibi on dokuzuncu yüzyıl Amerikan şairlerinden etkilenmiş olduğunu tanıtlamaktadır.

Anahtar Sözcükler: Tanrısallaştırma, Yeniden Doğuş, Paganizm, Yıldızlar, Yeryüzü, Ağıt, Pastoral, Gelenek

This article will attempt to unravel Dylan Thomas's use of stellar and terrestrial imagery in his poems, especially in elegies where the speaker grapples with life and death. What these images reveal is that Thomas's poetry aims to create and depict a pantheistic world that exists between the grass on the soil and stars in the sky. His is a cosmological poetics encapsulating almost everything from the minutest to the greatest. Exploring the way Thomas employs such stellar images may contribute to the elucidation of his allegedly obscure poetics as was put forward by Holbrook (1964), who found Thomas suffering from "dissociated phantasy-that which exerts a strong energy in the direction of avoiding reality and defending the self against it" (p. 9), or from lack of logic (p. 57), of meaning (p. 77) and of sense of rhythm (p. 91); thus these images will help situate him more accurately within the AngloAmerican poetic canon by laying bare the poets that influenced him in terms of these images.

The issue of placement is a significant one since Thomas has so far been seen as a parochial poet. Thomas's relationship and communication with American and some early Modernist poets have so far been neglected. Thomas has usually and aptly been associated with Welsh poetic tradition and various British authors such as Donne, Keats, Hopkins, Yeats, Lawrence and Joyce. There are also critics

\footnotetext{
${ }^{1}$ Dr., Ankara University, fahriozz@gmail.com
} 
who include surrealist poets among possible sources of influence, though this is a much disputed issue. Lucie-Smith (1987), for example, states that Thomas was influenced by the surrealists (p. 69), and Goodby (2013) observes "the early prose and poetry [of Dylan Thomas] exists in a fruitful dialogue with Surrealism" (p. 272) while according to Barbara Hardy (2000), Thomas differed radically from the surrealists in the way he resisted "the irrational, and the uncontrolled" (p. 43). Thomas's catalogue of influences is much wider and more complicated than these. A closer reading of his poems would also invite American poets such as Walt Whitman and Emily Dickinson. On one hand, like Keats and other Romantics, he has a tendency to consecrate human beings by placing them in a cosmological context. On the other, like Whitman, who adopted the voice of a cosmic prophet as well as a diurnal citizen, Thomas has a Janus-like quality bringing together earthly images with astronomical ones. It would be no hasty generalization to assert that Thomas's images range from the lowly blades of grass to distant constellations. McNees, approaching Thomas's poetry from a theological viewpoint, names this inclination as the "doubleness of sacred and secular", in which "he randomly intertwines natural, biological, and religious realms, and announces that all three are equally sacramental. He bases this conclusion on his own body, substituting himself for God and Christ and thereby assuming a prophetic authority" (p. 111). This two-headed imagery appears in early as well as late poetry of Thomas, especially in his elegiac poems, pointing to the wide range of his influences.

\section{"After the Funeral"2}

"After the Funeral" is one of the earliest elegies in which stellar and earthly images play a key role to show the tension between mortality and immortality. Thomas calls the poem he penned for his aunt as "the only one I have written that is, directly, about the life and death of one particular human being I knew" (W. Davies \& R. Maud, 1989, p. 223). Though he wrote other elegiac poems this one stands out in its directness and intimacy, revealing his emotional and artistic wavering about the death of his aunt. Written in 1933, revised 1938, and published in Life and Letters Today in 1938 (W. Davies \& R. Maud, 1989, p. 223), the poem appeared in his book Map of Love (1938).

In "After the Funeral" the body of the late Ann Jones oscillates between earth and heaven, between the grave she is lowered into and the sky to which Thomas promotes her. The lyric speaker is aware of the elegiac poet's dilemma which Ramazani (1994) cites as one of the defining traits of modern elegy, namely the persona's guilty conscience emanating from turning a tragic experience into an artistic opportunity (p. 6). As a mourner, Thomas finds it difficult to overcome this dilemma and at certain points in the poem he realizes that he is translating his grief into an aesthetic product and that he is not totally at ease with this apparently opportunistic act. Interestingly, at the very beginning of the poem the mourners are compared to mules braying, which implies the poet's incredulity of people's callous expression of grief and which also foreshadows his own exaggerated shower of emotions later in the poem:

After the funeral, mule praises, brays,

Windshake of sailshaped ears, muffle-toed tap

Tap happily of one peg in the thick

Grave's foot, blinds down the lids, the teeth in black,

The spittled eyes, the salt ponds in the sleeves,

Morning smack of the spade that wakes up sleep (p. 101)

Ackerman (1991) interprets the mourners' gush of emotion ("spittled eyes") as faking grief, "as though the mourners have been spitting on their eyes to feign tears" (p. 76). "Salt ponds" is obviously a hyperbole that lays bare mourners' lack of sincerity. Such metonymic and synecdochic signs of grief expressed by mule-like mourners with "sailshaped ears" are sham, which is also evident in the line "Morning smack of the spade that wakes up sleep" where the participants' displeasure is made manifest by having to wake up so early. This grotesque and funny treatment of the funeral cortege is rare in elegy as a genre and implies a transgression of elegiac conventions. When the speaker finds himself with the dead body of Ann in a room with stuffed animals and dry ferns his negative and doubtful

\footnotetext{
${ }^{2}$ All the quotations of Thomas's poems in this paper are from John Goodby's The Collected Poems of Dylan Thomas: The New Centenary Edition (2014).
} 
rendering of the mourners is balanced. His sombre description of the dead Aunt is a combination of realistic as well as hyperbolic tropes in alliterative lines:

I stand, for this memorial's sake, alone

In the snivelling hours with dead, humped Ann

Whose hooded, fountain heart once fell in puddles

Round the parched worlds of Wales and drowned each sun

(Though this for her is a monstrous image blindly

Magnified out of praise; her death was a still drop;

She would not have me sinking in the holy

Flood of heart's fame; she would lie dumb and deep

And need no druid of her broken body). (pp. 101-102)

The elegizing poet metamorphoses the lifeless Ann into a saint, a national protectress, a meteorological goddess securing fertility and regeneration with her bountiful showers. And thus, the speaker ironically associates himself with the mule-like "praises, brays" of the mourners carrying the coffin at the beginning of the poem. However, he does not end his high-blown consecration of which Ann would have been critical. Instead, he raises himself above this mortal setting by putting himself on a pedestal:

But I, Ann's bard on a raised hearth, call all

The seas to service that her wood-tongued virtue

Babble like a bellbuoy over the hymning heads, (p. 102)

This is of course a comic rendering of a prophetic speaker giving orders to the seas in a domestic setting. The lyric speaker plays or mimics, childishly perhaps, the role of the priest on the pulpit, orchestrating the whole ceremony. As the elegizing subject, Thomas attributes gigantic or heightened qualities to both himself and Ann, and thus attenuates the elegiac dilemma. In the rest of the poem he continues to elevate her into a symbol, an immortal object of admiration, in total contrast to her mortal self:

Her flesh was meek as milk, but this skyward statue

With the wild breast and blessed and giant skull

Is carved from her in a room with a wet window

In a fiercely mourning house in a crooked year. (p. 102)

Though her body is conceived in terms of earthly images ("meek as milk") Ann is heavenward bound ("skyward statue") and once again given a gigantic and regenerative image, as the rain drops on the "wet window" imply. The rest of the poem exhibits similar doubtful moves about the way the late aunt should be mourned.
I know her scrubbed and sour humble hands Lie with religion in their cramp, her threadbare Whisper in a damp word, her wits drilled hollow, Her fist of a face died clenched on a round pain; And sculptured Ann is seventy years of stone. These cloud-sopped, marble hands, this monumental Argument of the hewn voice, gesture and psalm Storm me forever over her grave until The stuffed lung of the fox twitch and cry Love And the strutting fern lay seeds on the black sill. (p. 102)

The lyric speaker swings back and forth between the real, mortal, earth-bound Ann and the one that resembles an Olympian goddess. The end-stopped line "And sculptured Ann is seventy years of stone" also involves a similar oscillation, expressing a down-to-earth fact with a grammatical twist. The use of the present tense points to Ann's immortalized condition while sculpture signals her translation into artistic or poetic expression. The sculpture of the aunt is, in a sense, the poem Thomas has written in memory of her, constructed out of, and interwoven with words. "Cloud-sopped marble hands" reads as a continuation of the swinging back and forth between the earth and sky, and between fact and fiction. In this quasi-surrealistic image Ann's hands are presented through a combination of domestic 
and quasi-mythological iconography. Sopped hands imply such chores as washing, cleaning, and cooking. However, modified by the word "cloud", this domestic image acquires the quality of a surrealist or Dadaist collage. The addition of marble further complicates the trope by juxtaposing words denoting aerial-light-liquid substances and those denoting hardness and durability. The hands can also be read as Ann's hands raised in prayer, which Thomas attempts to give a paganistic turn by adding a goddesslike quality. Despite these wavering statements, the poem ends optimistically with the possibility of resurrection heralded by the taxidermic fox uttering the word love and the dry ferns dropping their seeds. With love proclaimed and the fern seeds scattered propitiously the fertility rite is completed. Thus, the poet resolves the elegiac dilemma by accepting and performing his vatic, priestly role in a ritual of resurrection.

Such images in Dylan Thomas's poetry might lead one to see him as a surrealist poet. However, though he was widely read in surrealist poetry and took part in International Surrealist Exhibition in London in 1936, reading poems with Paul Éluard, Thomas does not agree with and stick to all the tenets of the surrealist movement. As Goodby (2013) explicates quite clearly and persuasively, Thomas was influenced by the Surrealist movement and this is apparent in some of his early poems such as "When like a running grave" and the sonnet sequence "Altarwise by owl-light" (2013, pp. 271-277; 2014, "Introduction", pp. xxxi-xxxiii). Nevertheless Thomas's relationship was not in the form of a total submission to the practice of his French fellow-poets. He agrees with the encyclopaedic definition of surrealism, which Breton sees "as an awareness of certain forms of associations previously neglected, but particularly immanent in the dream state, in sexual attractions, and in the free play of thought, creating heightened sensory perceptions that could open new vistas for the arts and help 'solve the principal problems of life"' (Balakian, 1993, p. 1234). It is difficult to say, however, that Thomas was a practitioner of automatic writing, which Breton explicated in his first manifesto of Surrealism in 1924. Automatic writing was meant to free the artist from the restrictions of reason and moral and aesthetic conventions. As Barbara Hardy (2000) indicates, "Thomas, (...) though like the surrealists in letting a flow of images 'make themselves' for him, was most unlike them in his declared attempt to apply 'to his images what intellectual and critical forces he possesses, allowing them to exist only within certain formal limits"' (pp. 43-44). Likewise Ackerman (1991) associates Surrealism with "the break with rational control, the use of imagery from the subconscious mind, and the application of art of Freudian psychology" (p.75), which Thomas did not approve. Still, the surrealistic images in Thomas's poetry cannot be ignored though he does not totally conform to surrealistic principles and methods.

His surrealist connection has its repercussions in the way he produces his poetic images. The juxtaposition of images of the earth and the sky, of fact and myth, of the domestic and the mythic is in fact in line with what Thomas says about the way he constructs his images in his letter to Henry Treece on Mach 1938:

\begin{abstract}
I make one image,--though "make" is not the word, I let, perhaps, an image be "made" emotionally in me and then apply to it what intellectual \& critical forces I possess-let it breed another, let that image contradict the first, make, of the third image bred out of the other two together, a fourth contradictory image, and let them all, within my imposed formal limits, conflict. Each image holds within it the seed of its own destruction, and my dialectical method, as I understand it, is a constant building up and breaking down of the images that come out of the central seed, which is itself destructive and constructive at the same time (1985, p. 281).
\end{abstract}

The images of mules braying with "sailshaped ears", cloud-sopped marble hands, and others in which seemingly incompatible items such as milk and statue are yoked together bear witness to Thomas's technique. The contradictory images belonging to different registers are reminiscent of his pagan philosophy in which life and death complement each other and form a cycle, it thus enables the reconciliation of the "skyward statue" and the grave after a sequence of various images related to earth and the sky in a ritual of regeneration.

\title{
"And death shall have no dominion"
}

Published first in New English Weekly in 1933 and three years later in Twenty-Five Poems, "And death shall have no dominion" is another poem that treats death and resurrection as synonymous or complementary events.Stand still, yet we will make him run. 
Each stanza starts and ends with the eponymous line that alludes to the Bible: "Knowing that Christ being raised from the dead dieth no more; death hath no more dominion over him" (Romans 6:9, King James Version). Despite this borrowing, assert W. Davies and R. Maud (1989), "the poem seems more pantheistic than Christian" (p. 209). Similarly, Tindall (1996) observes "these Christian references, proving only that Thomas had attended chapel, do not make this poem Christian" (p. 122). Goodby (2014) praises the poem as a significant piece in which "Thomas achieved for the first time a fusion of a pantheistic, apocalyptic vision and regular stanza form, rhyme, refrain and metre" (p. 241). Thomas's poem attempts to overcome mortality by means of a series of arguments. The beginning of the poem abounds in images of heavenly bodies and the sea:

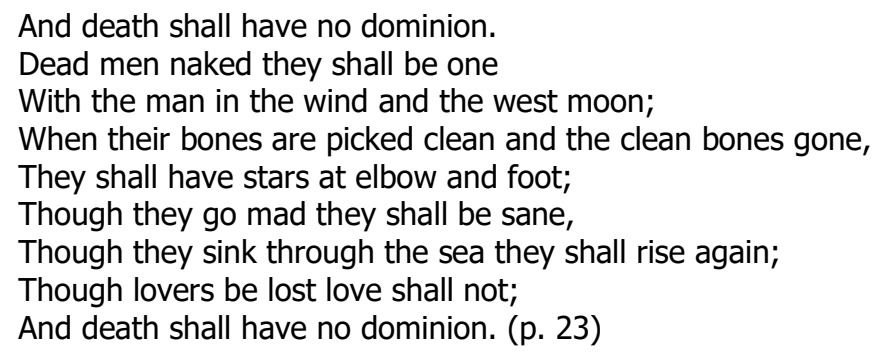

The dead men in the poem move towards the sky, as if not content with their existence on earth. Thomas jumbles phrases in the second line which should have read as "With the man in the west wind and the moon" (italics added). The dead are carried away like the way Shelley's (1986) persona who wishes to be mobilized and transformed into a poetically creative subject in his "Ode to the West Wind". Thus, these dead men or soldiers drifting in the air find themselves on the verge of being transformed into bafflingly huge representations over the moon and accompanied by "stars at elbow and foot". Thus they appear bigger and more powerful than death. Their end transforms them into saintly figures, adorned with gigantic astronomical entities.

Dylan Thomas develops the transformation of the dead by means of solar imagery. While the moon image in the first stanza implies an earlier phase in the transformation of man, the sun image, which stands for the life-giving force, suggests another phase in which the dead come alive and violently oppose the sun. This solar image in the final stanza stresses how resilient and determined the dead are once they have become part of the cycle of life:

Though they be mad and dead as nails, Heads of the characters hammer through daisies;

Break in the sun till the sun breaks down,

And death shall have no dominion. (p. 24)

Of course, death is never negated totally. Death exists but it can never defeat the life force in nature. The dead come back to life like daisies sprouting from the soil; so forceful is this drive to resurrect in the form of vegetation that these dead men can seize and capture the sun before it goes down for them. By assuming the power of the sun the dead rise above it. Thus the sun, the life-giving star becomes less powerful compared to the regenerative drive of the dead.

Goodby (2013), commenting on the parodic quality in the poem that arises from the tension between traditional form and vers libre, between pantheism and Biblical resurrection asserts that

Thomas's exaggerated parodic inversion of his usual technique for this single poem led him to deploy not just regular stanzas and rhyme, but iambic rhythms characterised by heavy stresses, end-stopping and parallel caesura, all of which were reinforced by alliteration, assonance and consonance well in excess of his usual style. In a manner owing something to Welsh hymn-singing and the hwy/of chapel sermons, these effects encourage a "primitive" identification of the rhythms of the sea and the cosmos, on the one hand, with those of physiological bases of verse rhythm in pulse, heartbeat and sexual arousal, on the other (p. 71).

In a sense, the poem appears also as a product of the tension between the physical and the spiritual, between the within-reach and out-of reach images of life. Thomas plays with the polysemy 
created by the implications of Biblical, pantheistic and war images which serve the idea that death can be overcome with the realization of the natural cycle.

\section{"Do not go gentle into that good night"}

Like "After the Funeral", which was written for his maternal aunt, "Do Not Go Gentle into That Good Night" is written for his father. It is another poem written for or about somebody other than the poet himself; however, unlike the former it has an indignant and protesting elegiac tone. The poem began to be written in 1945 when the poet's father's health collapsed and finished in 1951 (Davies, 1983, p. 81). According to Barbara Hardy (2000) "Do not go gentle into that good night" is a poem in which "the morbidity of genesis [is] transformed to an energetic way of dying" (p. 136). Based on the clash between light and darkness, between life and death, the poem attempts to translate death into something to shun through a series of arguments and seems unwilling to embrace the idea of apotheosis. From the first stanza to the last, the dying man is portrayed by means of images that aggrandize his position in the cosmos.

The old men in the first stanza, though incapacitated, are surprisingly but understandably capable of protesting against "the dying of the light" (p. 193) when faced with death. Similarly, men of wisdom also stand against death; they are wise because of their awareness of the inevitability and necessity of death. Maybe theirs is a late achieved wisdom; still there is rage since their wisdom fails to alter the bitter end. The good men in the third tercet suffer from the brunt of a similar disillusionment when they realize the futility of their good deeds. The next set of "Wild men who caught and sang the sun in flight" (p. 193) suggests people who have achieved great deeds thanks to their daring and genius. Upon realizing the price they have had to pay to achieve their wildness, they also suffer from disappointment. The image of the wild men catching and singing the sun alludes to the concluding couplet of "To His Coy Mistress" by Andrew Marvell (1986): "Thus, though we cannot make our sun/ Stand still, yet we will make him run". (p. 1388) Marvell's persona realistically and convincingly states the possibility and necessity of carpe diem especially when the sun/son homophone is taken into consideration. However, Thomas's persona deals with a sombre theme and is aware of the impossibility of catching the sun. He does not, in fact, consent to making the sun run since it would be synonymous with embracing death. juxtaposed:

Another paradoxical star image appears in the fifth tercet where sight and blindness are

Grave men, near death, who see with blinding sight

Blind eyes could blaze like meteors and be gay,

Rage, rage against the dying of the light. (p. 193)

These lines harbour a double entendre and an oxymoron at the same time. Grave men, men nearing death have literally blinding sight since their eyes are failing; blinding sight also implies their direct confrontation with death, as a result of which their eyes gain an extraordinary power of vision. The co-existence of blindness and sight is itself an oxymoron, with blindness standing for both physical lack of light and dawning of vision or inner light. This trope seems to be borrowed from the $19^{\text {th }}$ century American poet Emily Dickinson (1997):

Tell all the Truth but tell it slant -

Success in Circuit lies

Too bright for our infirm Delight

The Truth's superb surprise

As Lightning to the Children eased

With explanation kind

The Truth must dazzle gradually

Or every man be blind - (pp. 506-507)

Dickinson's poem is a kind of manifesto focusing on poetic language which, according to the poet, requires the translation of the factual into the metaphorical. In other words, poetry transforms blinding or dazzling truths into manageable experiences so that people can gradually internalize them. For Thomas' old men it is too late, they are blinded by their nearing end. However, even at that final 
moment their vision acquires a super power, a vision that tells them to "blaze like meteors and be gay". Therefore, life is still worth living, and death and its metonymic equivalent darkness should not be welcomed in any way. Thomas tends once again to connect the stellar and the terrestrial by means of comparing grave men's blind eyes to meteors illuminating the sky. If one assumes the word grave to mean a burying place, the line appears to draw a line between earthly death and heavenly immortality, symbolized by meteors. Thomas's poem is thematically redolent of Milton's (1986) "Blindness Sonnet" ("When I consider how my light is spent"), from which it diverges in tone and attitude. Both poems are based on images of light and dark. However, while Milton's persona finds consolation, Thomas's persona is far away from doing so, and demands fierce opposition to darkness and death. Milton's sonnet, a form that was imported into English poetry by Wyatt and matured at the hands of poets like Shakespeare and Milton himself, is the explication of stoicism and acceptance of one's fate. Thomas's villanelle, an originally foreign poetic form not very common in English poetry, on the other hand, refuses to embrace death and blindness.

Finally, the father, the addressee of enunciation in the poem, is paradoxically portrayed "on the sad height". The father nearing death in an act of ascension to the sky is not granted the comfortable acceptance of a symbolically heightened existence in death. The father occupies the sad and privileged status as a man nearing death and naturally deserves to be respected. The possession of this status paradoxically implies envy on the part of the lyric speaker. It is an elevated position, yet as in Keats's "Bright Star", it is distant, cold and lifeless. Thus, "Do not go gentle into that good night" negates the idea of pagan rebirth or Biblical resurrection and embraces life through a series of secular and religious images.

\section{"Fern Hill"}

Written in 1945, "Fern Hill" portrays the young Thomas as a poet-prophet endowed with the power to enchant and inspire his livestock, foxes and pebbles in the brook into song. The poem, though not an elegy, insinuates a kind of foreboding through passage of Time, which appears as a masculine overpowering presence. The opening line of the poem signals a dream-like pastoral setting:

Now as I was young and easy under the apple boughs

About the lilting house and happy as the grass was green,

The night above the dingle starry,

Time let me hail and climb

Golden in the heydays of his eyes,

And honoured among wagons I was prince of the apple towns

And once below a time I lordly had the trees and leaves

Trail with daisies and barley

Down the rivers of the windfall light. (p. 177)

Goodby (2014) reads the first line as a "grammatical paradox, an ambiguous tense between past and present", adding that the poem is not simply about what it means to be young "but how it feels to have been young, its easy-going manner belies its intricate constructedness (...). The narrative is that of growing towards death within sacramentalised nature, an exploration of the nature of innocence, which became the theme of much later late work" (pp. 401, 400). The green child in the pastoral does not at first recognise the destructive power of Time, whose sinister side becomes apparent only at the end of the poem. That is why the child-speaker portrays himself as a prince, the Christian God who designed the Garden of Eden or a powerful figure in control of everything.

Barbara Hardy (2000), who calls Thomas a green poet, observes how "the sand, water, bird, grass, stone and hill" are characterized "as live, individual, active participants" (p. 143) in his poems. Thomas indeed can be seen as a green poet, meditating on life and art by means of nature. In "Fern Hill" green grass and star-bedecked sky coexist showing the poet's desire to reconcile such distant images in the child's world.

In the rest of the poem, time is conceived by means of reiterated images of the sun and the moon, metonymic pairs that stand for day and night:

All the sun long it was running, it was lovely, the hay

Fields high as the house, the tunes from the chimneys, it was air 


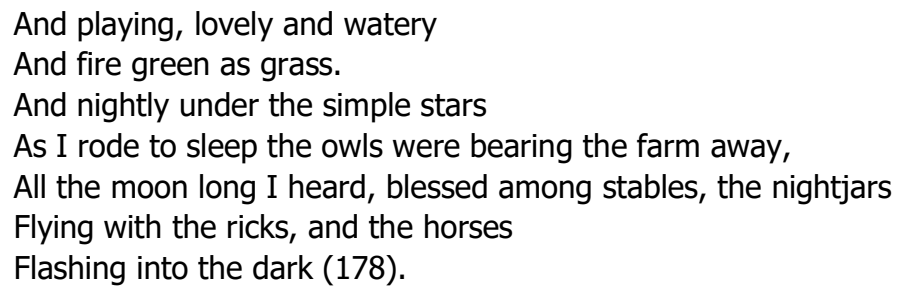

The child who lives in the Lacanian world of the Imaginary is away from the demarcations set through binary oppositions in the Symbolic order. The lyric speaker here identifies himself with other objects, setting no demarcations between himself and the outer world. The child is immersed in the signified aspect of the language, thus both the sun and the moon appear not as signifiers abut as signified. Through the phrases "All the sun long" and "All the moon long", foregrounded through parallel structure and paradigmatic deviation, these heavenly bodies are conceived as temporal units, that is, day and night. Thus the speaker's relationship with reality and language points to a fluid and volatile plane, which is also evident in the use of surrealistic images: owls carrying away the house, night-jars flying with ricks, horses flashing into darkness. The farm itself becomes an emblem of the Edenic Garden with "Adam and maiden". However, as the word choice suggests, Thomas opts for the word "maiden" rather than "Eve" since it would connote the Christian world of the Fall and the original sin, which would tarnish the secular, childlike pastoral world in the poem.

In the last stanza "the moon that is always rising" and "the sun born over and over" (p. 178) are replaced by Time which holds the lyric speaker "green and dying" (p. 179). This is the Time of the Symbolic order, the entry of the subject into language and its concomitant rules. The only compensation the speaker finds is through the art of poetry: "Though I sang in my chains like the sea" (p. 179). The end of the poem signals the end of "the lamb white days" (p. 178), yet this is an inevitable and necessary end. The poet-speaker dies into maturity, but at the same time, singing Orpheus-like, he is born into creativity and poetic discourse. The way he sings like the sea implies the apotheosis of the speaker from an experiencing subject into a signifying one on a grand scale. The pastoral world created in the poem is infused with the earthly pleasures of childhood and cosmic boundlessness which is finally transformed into the realization of the time- and space-bound physical world.

\section{Conclusion}

The analysis of these poems reveals that Thomas is a poet focusing on man's transient existence in the universe and that the images he uses serve to tackle with this tragic situation. The stellar imagery coexists with earthly ones, which implies Thomas's interest in life and death, religion and love of nature, among others. While terrestrial images imply the mortal side of man that is bound to decompose, stellar images point towards a pantheistic resurrection or apotheosis by becoming part of the natural cycle. Perhaps not incidentally, Thomas's poetry abounds in poems about beginnings and ends. He is a poet deeply concerned with man's mortality which he aims to transcend and relate to his readers by means of poetry.

Thomas's poems coincide with John Stuart Mills' definition of the lyric as something overheard, some personal utterance designed not for others but the lyric speaker himself; nevertheless, his alliterative and rhythmically rich lines suggest that his oeuvre transcends a solipsistic and isolated discourse. Thomas writes with the intention of reciting his poems whose performative quality attests to his desire to address a congregation of poetry lovers. In his "Poetic Manifesto" he elaborates on the Welsh rhythms of preachers, their oratory skills, the hwy/that he transposed and transferred into his work: "The great rhythms of [the Bible] rolled over me from the Welsh pulpit" (qtd. in R.N. Maud \& A.T. Davies, 1989, "Introduction" p. xix). Thomas aims at appealing to his audience like a priest in front of his congregation. Like a preacher delivering his sermon in ecstasy he borrows from a variety of sources even at the expense of perplexing them through his diverse images gleaned from disparate domains. That his message is chaotic and enigmatic makes his audience much more attentive to what he is delivering.

Another conclusion that can be reached about Thomas's poetry is that his poetic forefathers are not confined to British poets. Cohabitation of the bodily and the heavenly, the minutial and the 
cosmological in Thomas's poems points to what Goodby (2014) calls "'cognitive dissonance', getting [the poem] to say two opposing things at once, equally forcefully ("Introduction", xxi). This cohabitation also reveals Thomas's implicit connections with the American poet Walt Whitman, whose photograph hangs in his room along with those of Auden, Lawrence and Hardy (Thomas, 1995, p. 900). Whitman's poetry combines the vatic and the everyday; he juxtaposes his body and people from different walks of life and regions, blades of grass and meteors, present and future in his lyric-epic Song of Myself. Grass is one of the very common images implying his debt to Walt Whitman, whose Song of Myself begins and ends palindromically with the image of grass. Early in the poem, the poet-speaker portrays himself enjoying and becoming a part of nature: "I loafe and invite my soul, / I lean and loafe at my ease observing a spear of grass" (Whitman, 1976, p. 207). The celebration of and wonder at the significance of so minute a thing continues as the poet attributes more grand meanings to the grass:

A child said What is grass? fetching it to me with full hands,

How could I answer the child? I do not know what it is any more than he.

I guess it must be the flag of my disposition, out of hopeful green stuff woven.

Or I guess it is the handkerchief of the Lord,

A scented gift and remembrancer designedly dropt,

Bearing the owner's name someway in the corners, that we may see and remark, and say, Whose?

Or I guess the grass is itself a child, the produced babe of the vegetation (p. 210211).

Like Thomas, Whitman too sees human beings in a cosmological and timeless as well as natural and earth-bound context in other parts of his song. In song 52, which concludes this long poem, the poet speaker envisions his own death, decomposition, and rebirth in the form of vegetation: "I bequeath myself to the dirt to grow from the grass I love, / If you want me again look for me under your bootsoles" (1976, p. 256). Cowley (1983) argues that the grass symbolizes "the miracle of common things and the divinity (...) of ordinary things (p. 258). Such paganistic vision overlaps with that of Thomas, though Whitman's world tends to have more democratic concerns. Like Whitman, Thomas embraces diverse images to express the complexity and elusive quality of experience.

Thomas does not aspire to voice democratic concerns; however, he democratizes poetry and poetic image like Whitman. In this sense he goes much further than the Metaphysical poets in bringing together incompatible images with a sober voice. For instance, in his "Before I Knocked" he boldly employs anatomical images usually deemed unpoetic in a poem about religious experience: "My heart knew love, my belly hunger; / I smelt the maggot in my stool" (p. 39). Thus he uses scatological and visceral images in a poem dealing with Passion and Resurrection. In a letter to Glyn Jones, Thomas wrote: "My own obscurity is quite an unfashionable one, based, as it is, on a preconceived symbolism derived (I'm afraid all this sounds wooly and pretentious) from the cosmic significance of the human anatomy" (1985, p. 98). Some critics of Thomas (David Holbrook, 1964, for example) attacked him for his use of allegedly gross metaphors, without trying to understand the poet's underlying method and purpose. The influence of Surrealism and Freudian psychology on some of his poems may further illuminate the misleading impression of arbitrariness in the startling images he concocts.

\section{References}

Ackerman, J. (1991). Dylan Thomas: His life and work. London: Macmillan.

Balakian, A. (1993). Surrealism. The new princeton encyclopedia of poetry and poetics. Eds. Alex Preminger \& T. V. F. Brogan. Princeton: Princeton UP, 1234-1237.

The Holy Bible, King James Version. Ruby Text. London: Collins, 1958.

Cowley, M. (1983). An Analysis of 'Song of Myself'. Critical essays on Walt Whitman. Ed. James Woodress. Boston: G.K. Hall.

Davies, J. A. (1983) A reference companion to Dylan Thomas. Westport: Greenwood Press. 
Davies, W. \& R. Maud (Eds.)(1989). Dylan Thomas: The collected poems 1934-1953. London: Everyman.

Dickinson, E. (1997). The complete poems. Ed. Thomas H. Johnson. New York: Back Bay.

Goodby, J. (ed) (2014). The collected poems of Dylan Thomas: The new centenary edition. London: Weidenfeld and Nicolson.

Goodby, J. (2013). The poetry of Dylan Thomas: Under the spelling wall. Liverpool: Liverpool UP. Hardy, B. (2000). Dylan Thomas: An original language. Athens: The University of Georgia Press.

Hardy, B. (1989). The personal and the impersonal in some of Dylan Thomas's lyrics. Critical essays on Dylan Thomas. Ed. Georg Gaston. Boston: G.K. Hall, 133-139.

Holbrook, D. (1964). Dylan Thomas and poetic dissociation. Carbondale: Southern Illinois UP.

Lucie-Smith, E. (Ed) (1987). British poetry since 1945. Harmondsworth: Penguin, 1987.

Marvell, A. (1986): To his coy mistress. Norton anthology of English literature. M.H. Abrams (Ed.). Fifth Edition. New York: Norton, 1387-1388.

Maud, R. N. \& A. T. Davies (Eds) (1989). The colour of saying: An anthology of verse spoken by Dylan Thomas. London: Everyman.

McNees, E. J. (1991). Eucharistic poetry: The search for presence in the writings of John Donne, Gerard Manley Hopkins, Dylan Thomas, and Geoffrey Hill. Lewisburg: Bucknell UP.

Milton, J. (1986). When i consider how my light is spent. The Norton anthology of English literature. $5^{\text {th }}$ ed. Vol.1. Gen. ed. M.H. Abrams. (1443).New York: Norton.

Ramazani, J. (1994). Poetry of mourning: The modern elegy from Hardy to Heaney. Chicago: University of Chicago Press.

Shelley, P. B. (1986). Ode to the West Wind. The Norton anthology of English literature. $5^{\text {th }}$ ed. Vol. 2. Gen. ed. M.H. Abrams. New York: Norton, 696-698.

Thomas, D. (1985). The collected letters. Ed. by Paul Ferris. New York: Macmillan.

Tindall, W.Y. (1996). A Reader's guide to Dylan Thomas. New York: Syracuse UP.

Whitman, W. (1976). Song of myself. The new Oxford book of American verse. Chosen and Edited by Richard Ellmann. New York: Oxford UP, 207-256. 